\title{
Corporate Social Responsibility and Competitive Advantage: Relationships and Mechanisms
}

\footnotetext{
Submitted 24/4/20, $1^{\text {st }}$ revision 20/05/20, $2^{\text {nd }}$ revision 18/06/20, accepted 20/07/20

\author{
Mohammed L. Ashour ${ }^{1}$, Nafez N. Ali ${ }^{2}$, Mahmoud S. Allan ${ }^{3}$
}

Abstract:

Purpose: This study is intended to gain insight into the association of Corporate Social Responsibility (CSR) implementations and the achievement of competitive advantage focusing on the mediation role of company reputation $(C R)$ in this relationship.

Design/Methodology/Approach: Semi-structured interview technique was used to confirm the validity of the research model. In addition, the purposive sampling method has been used targeting senior decision makers in different well-known 5-star hotels and resorts in Jordan. A total of three hundred (300) questionnaires were distributed. While two hundred and forty (240) questionnaires were retrieved from respondents, two hundred and eleven (211) questionnaires were valid and usable.

Findings: The results elucidated the mechanism of CSR and competitive advantage relationship. Although the results confirmed the positive (direct and indirect) effect of the social, the legal, and the ethical dimensions of (CSR) on competitive advantage, data analysis did not support any significant impact for the environmental dimension on competitive advantage (CA) through the company reputation $(C R)$ as a mediator variable.

Practical Implications: This study raises awareness of (CSR) implementations in serviceoriented developing economies through highlighting the mechanism and relationships of CSR and competitive advantage. It is hoped that, it will contribute to generate interest towards the concept of "Environmental Corporate Social Responsibility" (ECSR), as a strategic alternative at the aim of the achievement of competitive advantage.

Originality/Value: The study goes beyond examining the causal relationship between (CSR) and competitive advantage. It focuses on achieving a deep understanding of this relationship by exploring the mechanisms of its work through illustrating the mediation role of reputation.
}

Keywords: Corporate Social Responsibility, competitive advantage, tourism, and hospitality.

JEL Code: M14, M31, Z33.

Paper Type: Research study.

${ }^{1}$ Corresponding author, Al-Zaytoonah University of Jordan, m.ashour@zuj.edu.jo

${ }^{2}$ Al-Zaytoonah University of Jordan, n.ali@zuj.edu.jo

${ }^{3}$ Al-Zaytoonah University of Jordan, mahmoud.allan@zuj.edu.jo 


\section{Introduction}

In today's competitive business environment, Corporate Social Responsibility (CSR) has become increasingly more important as a strategic approach. The early 1950s saw the start of the modern era of CSR when it was more commonly known as social responsibility. Peter Drucker (1954) was one of the first to explicitly address public responsibility as main key success areas for businesses. According to Drucker, although making profits represents firm's primary goal, managements should consider the impact of every business policy and action upon society. In recent years, scholars have devoted increased attention to the different implications of corporate social responsibility and its relationship with competitive advantage (Galant and Cadez, 2017; Becchetti and Trovato, 2011; Aras et al., 2010; Filho et al., 2010).

The Tourism and hospitality sector in Jordan is considered a vital one as it contributes up to more than US\$ 800 million to the country's sluggish economy and accounts for approximately 10 percent of Gross Domestic Product (GDP) (IndexMundi, 2019). However, within the last few years the fierce competition in the tourism market led to a decrease in the number of international tourists, which in turn decreased tourism contribution to GDP from (12\%) in 2011 to (10\%) in 2019 (UNPA, 2019). Hence, this research is an attempt to contribute to the development of the Jordanian tourism industry through evaluating the influence of social responsibility implementations represented by social, ethical, environmental, and legal aspects on the achievement of competitive advantage (Zieliński and Jonek-Kowalska, 2020).

\section{Literature Review}

Related literature viewed corporate social responsibility from different standpoints; Williams (2002) stated that it is a commitment of the business sector to follow up the policies and the businesses that benefit society. Ha-Brookshire (2017) defined it as the moral responsibility of the organization toward stakeholders. While the study conducted by Jones (1999) highlighted CSR influence on the community which is reflected in business decision making, Noyan and Bostanci (2013) discussed how environmental values can affect corporate perception.

The early study of Carroll (1979) and the latest study by Wolska et al. (2020) offered the foundational concepts of CSR aspects, in which ethical and legal activities of CSR were indicated in the proposed ,,three dimensional conceptual model“. In addition to other variables, ethical and legal activities were also taken into account by Saeed and Arshad (2012), and Soelton et al. (2020) as main external factors that positively influence firms' organizational performance. Similarly, Zsolnai (2006) focused on the ethical aspect while evaluating the linkage between competitiveness and corporate social responsibility. Many CSR studies focused on selected financial indicators while assessing CRS influence on firms` organizational performance. The study of Abbott and Monsen (1979) tracked the change over time of corporations' social involvement, and examined its effects on corporate profitability. In the same line of argument, 
Roman et al. (1999) investigated the potential relationship between firms' social considerations and financial performance. Margolis et al. (2011) examined the relationship between corporate social responsibility and financial performance through conducting a meta-analysis of 192 effects revealed in 167 studies between 1972 and 2006 where the overall effect was positive. In addition, O'brien (2001) focused on the strategic aspects of social responsibility through examining the association of both of social responsibility and the achievement of competitive advantage. O’brien`s (2001) main question was “how to create socially anchored competencies (SACs) that can be used to benefit society as well as increase profitability "?

Gond et al. (2010) discussed how CSR contributes to corporate performance by influencing employees` behavior, Hick (2000) explained how the ethical aspects of CSR can support firms' ability to maximize profits. Similarly, the strong relationship between profitably and CSR was indicated by Joshi, Sun and Mann (2010). From a strategic management viewpoint, Fulop, Hisrich and Szegedi (2000) pointed out a shortcoming related to CSR practices which was attributed to the firm's lack of knowledge and the extensive focus on survival as a major objective pursued by companies compared to moral responsibility.

Focusing on Jordan's tourist environment, Muala and Qurneh's research (2012) aimed at exploring the relationship between three key variables, namely, marketing mix, satisfaction, and loyalty in the curative tourism industry in Jordan. Weshah et al. (2012) indicated the positive effect of firms' size as a moderator variable when examining the relationship of CSR and the organizational performance. The study of Futa (2013) highlighted the linkage between the citizenship behavior of employees and social responsibility activities of tourist organizations in Jordan. Although the results brought to light the positive association between selected philanthropic, legal, or economic CRS activities and employee citizenship behavior, the linkage between CSR and firm organizational performance was not highlighted. Similarly, the research of Al Qeed (2014) also gave great attention to the internal CRM activities that are directed toward employees when examining CSR relationship with businesses performance.

Within a more comprehensive perspective including the internal and external dimensions of CSR, the study held by Al Rousan et al. (2015) illustrated the influence of integrating the stakeholder theory (Freeman, 1984) into CSR practices by employing a specific group of stakeholders. The study pointed out how a tourism business environment in Jordan can provide new methods to implement both internal and external aspects of CSR. In the same line of argument, Al-Saida (2015) stressed the need for continuous efforts to meet the social responsibilities, paying more attention to human resources in the surrounding communities, and providing more support to the community through having a role in creating attractive tourist environment such as resorts and artificial lakes etc. 
Accordingly, it could be argued that, although the CRM-competitive advantage relationship was heavily studied by many researchers, there still remains a need for more efforts in explaining the mechanisms of this relationship and the mediation role of specific variables such as company reputation or customer satisfaction especially in services markets where the building and sustaining of competitive advantage is seen as a challenging task.

\section{Methodology}

As a preliminary phase, in order to confirm the validity of the adopted dimensions of the study model, semi-structured interviews were conducted with a selected group of experts and senior managers from the tourism sector in Jordan. Accordingly, the research's theoretical framework was developed at the aim of assessing the indirect and direct effects for independent and mediator factors influencing competitive advantage as shown in Figure 1 below. Thus, a questionnaire was used as a main data collection tool, which included the four aspects of social responsibility, social dimension (SD), ethical dimension (ED), environmental dimension (Env. D), and the legal dimension (Leg. D). A total of three hundred (300) questionnaires were distributed. While two hundred and forty (240) questionnaires were retrieved from respondents, two hundred and eleven (211) questionnaires were valid and usable.

Figure 1. Research Theoretical Framework

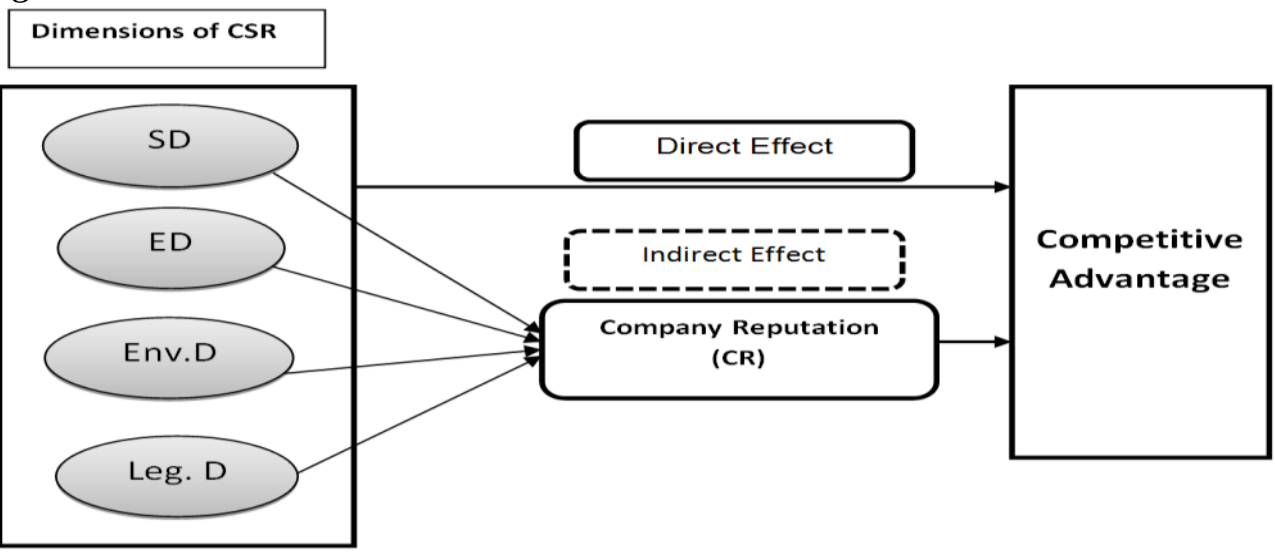

Source: Authors.

In addition, as the study aimed to evaluate the relationship of corporate social responsibility implementations on the achievement of competitive advantage, hence, both competitive advantage (CA) and company reputation (CR) (as a mediator variable) were represented in the developed questionnaire. As shown in Table 1 below, the implementation of the research data collection plan was accomplished in four constitutive steps.

\section{Data Analysis}


Reliability refers to consistency or accuracy in measurement. With regard to Cronbach's alpha values related to the statements of the instrument it ranged from 0.746 to 0.920 as shown in Table 2 below. Thus, Cronbach's alpha values indicate an obvious consistency among the respondents' answers suggesting a good degree for overall reliability of the used tool (Cronbach and Shavelson, 2004, 391-418).

Table1. Practical Stages of Research Plan

\begin{tabular}{|c|c|c|}
\hline Stage & Purpose & Target Sample/ Justification \\
\hline $\begin{array}{l}\text { Stage (1) } \\
\text { Preliminary }\end{array}$ & $\begin{array}{l}\text { Investigating the key } \\
\text { informant persons in the } \\
\text { tourism and hospitality sector } \\
\text { in Jordan }\end{array}$ & $\begin{array}{l}\text { Experts, general managers, executives, public } \\
\text { relations managers in Jordan's tourism and } \\
\text { hospitality sector ( in Dead Sea area and Aqaba } \\
\text { special economic zone authority) }\end{array}$ \\
\hline $\begin{array}{l}\text { Stage (2) } \\
\text { Collecting } \\
\text { Qualitative } \\
\text { data }\end{array}$ & $\begin{array}{l}\text { - Examining the validity of the } \\
\text { study's model and its four } \\
\text { dimensions at the aim of } \\
\text { developing the study data } \\
\text { collection tool (questionnaire) } \\
\text { in the subsequent stages. } \\
\text { - Data collection tool at this } \\
\text { stage is a semi-structured } \\
\text { interview (using a digital } \\
\text { voice recorder) }\end{array}$ & $\begin{array}{l}\text { Senior decision makers as general managers, } \\
\text { executive managers, PR managers in tourism and } \\
\text { hospitality sector from different well-known 5-star } \\
\text { hotels and resorts in Aqaba special economic zone } \\
\text { authority. } \\
\text { Local community representatives in both: the city } \\
\text { of Aqaba and Dead Sea area as two major tourist } \\
\text { destinations in Jordan) }\end{array}$ \\
\hline $\begin{array}{l}\text { Stage (3) } \\
\text { Collecting } \\
\text { Quantitative } \\
\text { Data }\end{array}$ & $\begin{array}{l}\text { This stage represents a main } \\
\text { practical part of the research } \\
\text { plan (stage of data collection } \\
\text { using questionnaire). }\end{array}$ & $\begin{array}{l}\text { Basing on the study model, the target sample } \\
\text { represents employees working in private hotel and } \\
\text { tourism institutions (not public because of the } \\
\text { adoption of the study model on the axis of } \\
\text { competitive advantage as a performance provider } \\
\text { exclusively related to private sector institutions). }\end{array}$ \\
\hline $\begin{array}{l}\text { Stage (4) } \\
\text { Complemen } \\
\text { tary of Data } \\
\text { Collection }\end{array}$ & $\begin{array}{l}\text { To increase the size and the } \\
\text { quality of the collected data } \\
\text { by targeting a more number of } \\
\text { respondents from well-known } \\
\text { and leading } 5 \text { star hotels such } \\
\text { as: } \\
\text { Kempinski Hotel/ MARINA } \\
\text { Plaza Hotel/ Movenpick } \\
\text { Resort }\end{array}$ & $\begin{array}{l}\text { The adopted strategy of data analysis required initial } \\
\text { evaluation of quality of quantitative collected data } \\
\text { by the questionnaire. } \\
\text { This phase aimed to raise the quality of the data } \\
\text { collected by targeting a larger number of } \\
\text { respondents from leading service organizations } \\
\text { (with more experiences and programs related to } \\
\text { the subject of the study/ Social Responsibility } \\
\text { which is expected to improve the credibility of } \\
\text { research findings. }\end{array}$ \\
\hline
\end{tabular}

\section{Source: Authors.}

In addition, to ensure the model is properly specified and functioning correctly, variance inflation factor (VIF) test was used to verify that there is no multicollinearity between the independent variables as shown in Table 3 below.

The results in Table 3 indicate that there is no multicollinearity between the independent variables (social responsibility related dimensions) represented in social, ethical, environmental, and legal variables. This was confirmed by the calculated values of (VIF) for these dimensions of $(1.424,1.467,1.882$, and 1.944) respectively, and all the calculated values of (VIF) were less than the critical value of the test (10). 
Table 2. Reliability analysis using Cronbach's alpha $(\alpha)$ coefficient

\begin{tabular}{||l||l|l||}
\hline Main \&Sub. Variables & Statements Numbers & Cronbach's alpha $(\boldsymbol{\alpha})$ coefficient \\
\hline \hline $\begin{array}{l}\text { Social Responsibility } \\
\text { Dimensions: }\end{array}$ & 20 & 0.866 \\
\hline \hline Social Dimension & 5 & 0.746 \\
\hline Ethical Dimension & 5 & 0.712 \\
\hline Environmental Dimension & 5 & 0.842 \\
\hline Dimension Legal & 5 & 0.785 \\
\hline \hline $\begin{array}{l}\text { Mediator Variables } \\
\text { Company Reputation }\end{array}$ & 5 & 0.816 \\
\hline \hline Competitive Advantage & 6 & 0.789 \\
\hline \hline Total & 31 & 0.920 \\
\hline
\end{tabular}

Source: Authors.

Table 3. Results of the (VIF) test to verify of multicollinearity phenomenon between Independent Variables

\begin{tabular}{||l||l||l||l||l||}
\hline No. & Social Responsibility Dimensions & Tolerance & VIF & $\begin{array}{l}\text { Critical value } \\
\text { of the test }\end{array}$ \\
\hline \hline 1 & Social Dimension (SD) & 0.702 & 1.424 & 10 \\
\hline 2 & Ethical Dimension (ED) & 0.682 & 1.467 & 10 \\
\hline 3 & Environmental Dimension (Env. D) & 0.531 & 1.882 & 10 \\
\hline 4 & Legal Dimension (LD) & 0.514 & 1.944 & 10 \\
\hline
\end{tabular}

Source: Authors.

\subsection{Results of Testing the Impact of Social Dimension (SD) on Company Reputation (CR) as a Mediator}

H0.1: There is no statistically significant impact at the significance level $(\alpha \leq 0.05)$, for the social dimension (SD) on company reputation $(C R)$ :

To test the validity of the previous hypothesis, a simple linear regression technique was used as shown in Table 4 below:

Table 4. Results of simple linear regression analysis, to measure the impact of (SD) on $(C R)$

\begin{tabular}{||l|l|l||l||l||}
\hline \hline Independent Variable & Coefficients $(\boldsymbol{\beta})$ & Std. Error & t- value & Sign. \\
\hline Constant $(\beta 0)$ & 2.831 & 0.209 & 13.578 & 0.000 \\
\hline Social dimension & 0.299 & 0.052 & $5.797^{*}$ & 0.000 \\
\hline \hline Correlation coefficient $(\mathrm{R})=0.372$ & Determination coefficient $(\mathrm{R} 2)=0.138$ \\
\hline F- value $=33.606$ & Sig. of $(\mathrm{F})=0.000$ \\
\hline
\end{tabular}

Note: $\{$ T-tabulation with $d f .=(209)$ at the significance level $(\alpha=0.05)\}=1.96$

$\{F$-tabulation with degrees of freedom $(1,209)$, at the significance level $(\alpha=0.05)\}=3.84$

Source: Authors.

The results in Table 4 indicate the following: 
The validity of the simple linear regression model is proven, this is confirmed by the calculated value of $(F)=(33.606)$, which is greater than F-tabulation (3.84), and the statistical significance of $(F)$ equals to (0.000) is less than the significance level $(\alpha=0.05)$.

$>$ The value of the determination coefficient $(\mathrm{R} 2=0.139)$, indicates that the change in the (SD) dimension, explains $(13.9 \%)$ of the changes that occur in company reputation (CR).

$>$ The statistically significant regression coefficient $(\beta)$ of the social dimension is proven. This was supported by the calculated $t$-value $=(5.797)$, which is greater than the t-tabulation (1.96), and the statistical significance (sign) for this dimension is less than the significance level $(\alpha=0.05)$. Thus the null hypothesis (H0.1) was rejected, and the alternative hypothesis (H1.1) was accepted which states that there exists a statistically significant impact at the significance level $(\alpha \leq 0.05)$, for the social dimension on the company's reputation.

\subsection{Results of Testing the Impact of the Ethical Dimension (ED) on Company Reputation (CR) as a Mediator}

H0.2: There is no statistically significant impact at the significance level $(\alpha \leq 0.05)$, for the ethical dimension on company reputation $(C R)$ :

To test the validity of the previous hypothesis, a simple linear regression method was used as shown in Table 5 below:

Table 5. Results of a simple linear regression analysis, to measure the impact of (ED) dimension on company reputation $(C R)$

\begin{tabular}{||l||l|l|l|l||}
\hline Independent Variable & Coefficients $(\boldsymbol{\beta})$ & Std. Error & t- value & Sign. \\
\hline \hline Constant $(\beta 0)$ & 1.914 & 0.280 & 6.840 & 0.000 \\
\hline Ethical dimension & 0.519 & 0.068 & $7.587^{*}$ & 0.000 \\
\hline \hline Correlation coefficient $(\mathrm{R})=0.465$ & Determination coefficient $(\mathrm{R} 2)=0.216$ \\
\hline F- value $=57.558$ & Sig. of $(\mathrm{F})=0.000$ \\
\hline
\end{tabular}

Note: $\{$ T-tabulation with $d f .=(209)$ at the significance level $(\alpha=0.05)\}=1.96$

$\{F$-tabulation with degrees of freedom $(1,209)$, at the significance level $(\alpha=0.05)\}=3.84$

Source: Authors.

The results in Table 5 indicate the following:

$>$ The validity of the simple linear regression model is proven, this is confirmed by the calculated value of $(\mathrm{F})=(57.558)$, which is greater than F-tabulation (3.84), and the statistical significance of $(\mathrm{F})$ equals to $(0.000)$ is less than the significance level $(\alpha=0.05)$.

$>$ The value of the determination coefficient $(\mathrm{R} 2=0.216)$, indicates that the change in the ethical dimension, explains $(21.6 \%)$ of the changes that occur in company reputation.

$>$ Statistical significance of the regression coefficient $(\beta)$ of the ethical dimension was proven. This was supported by the calculated t-value = (7.587), which is greater than the t-tabulation (1.96), and the statistical 
significance (sign) for this dimension is less than the significance level $(\alpha=$ 0.05). Thus the null hypothesis (H0.2) was rejected, and the alternative hypothesis (H1.2) was accepted which states that there exists a statistically significant impact at the significance level $(\alpha \leq 0.05)$, for (ED) dimension on the company reputation.

\subsection{Results of Testing the Impact of the Environmental Dimension (Env. D) on Company Reputation (CR) as a Mediator}

H0.3: There is no statistically significant impact at the significance level $(\alpha \leq 0.05)$, for the environmental dimension on company reputation $(C R)$ :

To test the validity of the previous hypothesis, a simple linear regression method was used as shown in Table 6 below:

Table 6. Results of a simple linear regression analysis, to measure the impact of (Env.D) dimension on company reputation $(C R)$

\begin{tabular}{||l|l||l||l|l||}
\hline \hline Independent Variable & Coefficients $(\boldsymbol{\beta})$ & Std. Error & t- value & Sign. \\
\hline \hline Constant $(\beta 0)$ & 2.227 & 0.215 & 10.358 & 0.000 \\
\hline $\begin{array}{l}\text { Environmental } \\
\text { dimension }\end{array}$ & 0.175 & 0.127 & 1.378 & 0.069 \\
\hline \hline Correlation coefficient $(\mathrm{R})=0.214$ & Determination coefficient $(\mathrm{R} 2)=0.046$ \\
\hline F- value $=3.654$ & Sig. of $(\mathrm{F})=0.069$ & \\
\hline
\end{tabular}

Note: $\{$ T-tabulation with $d f .=(209)$ at the significance level $(\alpha=0.05)\}=1.96$

$\{F$-tabulation with degrees of freedom $(1,209)$, at the significance level $(\alpha=0.05)\}=3.84$

Source: Authors.

The results in Table 6 indicate the following:

$>$ The validity of the simple linear regression model is not proven, this result is confirmed by the calculated value of $(F)=(3.654)$, which is less than Ftabulation (3.84), and the statistical significance (sign.) of (F) equals to $(0.069)$ is greater than the significance level $(\alpha=0.05)$.

$>$ The value of the determination coefficient $(\mathrm{R} 2=0.046)$, indicates that the change in the environmental dimension (Env. D), explains just (4.6\%) of the changes that occur in the company reputation.

$>$ Statistically significant regression coefficient $(\beta)$ of the environmental dimension was not proven. This is supported by the calculated t-value = (1.378), which is less than the t-tabulation (1.96), and the statistical significance (sig. $=0.069)$ for this dimension is greater than the significance level $(\alpha=0.05)$. Thus, the null hypothesis (H0.3) was accepted, which states that there is no statistically significant impact at the significance level ( $\alpha \leq$ 0.05), for the environmental dimension (Env. D) on company reputation.

\subsection{Results of Testing the Impact of the Legal Dimension (Leg. D) on Company Reputation (CR) as a Mediator}


H0.4: There is no statistically significant impact at the significance level $(\alpha \leq 0.05)$, for the (Leg. D) dimension on the company reputation $(C R)$ :

To test the validity of the previous hypothesis, a simple linear regression method was used as shown in Table 7 which indacates the following:

$>$ The validity of the simple linear regression model is proven, this was confirmed by the calculated value of $(F)=(124.754)$, which is greater than $F$ tabulation (3.84), and the statistical significance of $(F)$ equals to $(0.000)$ is less than the significance level $(\alpha=0.05)$.

$>$ The value of the determination coefficient $(\mathrm{R} 2=0.374)$, indicates that the change in the (Leg. D), explains (37.4\%) of the changes that occur in company reputation $(\mathrm{CR})$.

$>$ The statistical significance of the regression coefficient $(\beta)$ of (Leg. D) is proven. This is supported by the calculated t-value $=(11.169)$, which is greater than the t-tabulation (1.96), and the statistical significance (sign) for this dimension is less than the significance level $(\alpha=0.05)$. Thus, the null hypothesis (H0.4) was rejected, and the alternative hypothesis (H1.4) was accepted which states that there exists a statistically significant impact at the significance level $(\alpha \leq 0.05)$, for the legal dimension (Leg. D) on the company reputation.

Table 7. Results of simple linear regression analysis, to measure the impact of (Leg. D) dimension on company reputation $(C R)$

\begin{tabular}{|l|l||l||l|l|}
\hline Independent Variable & Coefficients $(\boldsymbol{\beta})$ & Std. Error & t- value & Sign. \\
\hline \hline Constant $(\beta 0)$ & 1.611 & 0.218 & 7.396 & 0.000 \\
\hline Legal dimension & 0.595 & 0.053 & $11.169^{*}$ & 0.000 \\
\hline \hline Correlation coefficient $(\mathrm{R})=0.611$ & Determination coefficient $(\mathrm{R} 2)=0.374$ \\
\hline F- value $=124.754$ & Sig. of $(\mathrm{F})=0.000$ & \\
\hline
\end{tabular}

Note: $\{$ T-tabulation with $d f .=(209)$ at the significance level $(\alpha=0.05)\}=1.96$

$\{F$-tabulation with degrees of freedom $(1,209)$, at the significance level $(\alpha=0.05)\}=3.84$

Source: Authors.

\subsection{Results of Testing the Hypothesis Related to Company Reputation (CR) Variable as a Mediator}

H0.5: There is no statistically significant impact at the significance level $(\alpha \leq 0.05)$, for the social responsibility dimensions represented by the (social, ethical, environmental, and legal) on the competitive advantage (CA) through company reputation $(C R)$ as a mediator variable:

Before testing the hypothesis (H0.5), the model has been checked and verified for testing as shown in the following Table 8 . The results listed in Table 8 indicate the verification fit of the model. This result was supported by the calculated value of (Chi square $=41.589)$, which is statistically significant at the significance level $(\alpha \leq 0.05)$. Also, the results indicate the values of Goodness of Fit Index and Comparative Fit Index which are equals to (0.898) and (0.976) respectively, and these values approach 
to the "one' integer". In addition, the value of Root Mean Square Error is approaching to "zero", which it equals to (0.057).

Table 8. Goodness of fit (model testing for direct \& indirect effects)

\begin{tabular}{|l||l||l|l|l|l|}
\hline The statement & $\begin{array}{l}\text { Chi 2 } \\
\text { Value }\end{array}$ & $\begin{array}{l}\text { GFI* Defult } \\
\text { Model }\end{array}$ & $\begin{array}{l}\text { CFI** Defult } \\
\text { Model }\end{array}$ & $\begin{array}{l}\text { RMSEA**** } \\
\text { Defult Model }\end{array}$ & Sig. \\
\hline $\begin{array}{l}\text { Impact of (SD, ED, } \\
\begin{array}{l}\text { Env.D, Leg.D) on } \\
\text { (CA) through (CR) } \\
\text { as a mediator }\end{array}\end{array}$ & 41.589 & 0.898 & 0.976 & 0.057 & 0.000 \\
\hline
\end{tabular}

Note: * GFI: Goodness of Fit Index, and its value is approach to the "one' integer".

** CFI: Comparative Fit Index, and its value is approach to the "one' integer".

*** RMSEA: Root Mean Square Error and its value is approach to "zero".

Source: Authors.

The main issue of this study is revolving around the mechanism of CSR and competitive advantage (CA) relationship and the mediating role of company reputation (CR) in this association. Thus, to test the validity of the above hypothesis (H0.5), it was divided into two statements based on the direct and the indirect impact of (CR) on (CA) as follows:

$>$ H0.5.a: There is no statistically significant direct impact at the significance level $(\alpha \leq 0.05)$, for the social responsibility dimensions represented by (SD, ED, Env. D, Leg.D) on competitive advantage (CA);

$>$ H0.5.b: There is no statistically significant indirect impact at the significance level $(\alpha \leq 0.05)$, for the social responsibility dimensions represented by (SD, ED, Env. D, Leg.D) on competitive advantage (CA) through company reputation $(\mathrm{CR})$ as a mediator variable.

Accordingly, path analysis method was used through the statistical applications of (AMOS) software as Table 9 below shows to measure the impact of CSR dimensions (SD, ED, Env.D, Leg.D) on competitive advantage (CA) through company reputation $(\mathrm{CR})$ as a mediator variable. The results from Table 9 show that, the statistically significance of the regression coefficients $(\beta)$ is proven for (SD, Leg.D), which is related to the indirect effects. This is supported by calculated values of (t) for the above dimensions, as well as the statistical significance values ( $p$-value) for the mentioned dimensions are less than the significance level $(\alpha=0.05)$. So, there exists a statistically significant indirect impact for the social responsibility dimensions represented by (SD, Leg.D) on the competitive advantage (CA) through company reputation $(\mathrm{CR})$ as a mediator variable.

Taking into account the above findings, the null hypothesis (H0.5.b) was rejected partially and the alternative hypothesis (H1.5.b) that was accepted stating that there exists a statistically significant indirect impact at the significance level $(\alpha \leq 0.05)$, for 
the social responsibility dimensions represented by (SD, Leg.D) on competitive advantage (CA) through company reputation $(\mathrm{CR})$ as a mediator variable.

Table 9. Results of (Path Analysis)

\begin{tabular}{|l||l||l|l||l|l||}
\hline $\begin{array}{l}\text { Study } \\
\text { Variables }\end{array}$ & $\begin{array}{l}\text { Coefficients } \\
(\boldsymbol{\beta})\end{array}$ & $\begin{array}{l}\text { Std. } \\
\text { Error }\end{array}$ & t- value & P-value & $\begin{array}{l}\text { Type } \\
\text { Effect }\end{array}$ \\
\hline \hline $\mathrm{SD} \rightarrow \mathrm{CR}$ & 0.236 & 0.051 & $4.627^{* *}$ & 0.001 & Direct effect \\
\hline $\mathrm{ED} \rightarrow \mathrm{CR}$ & 0.216 & 0.070 & $3.086^{*}$ & 0.002 & Direct effect \\
\hline Env.D $\rightarrow$ CR & 0.148 & 0.139 & 1.065 & 0.078 & Direct effect \\
\hline Leg.D $\rightarrow$ CR & 0.347 & 0.070 & $4.957^{* *}$ & 0.000 & Direct effect \\
\hline \hline $\mathrm{CR} \rightarrow \mathrm{CA}$ & 0.591 & 0.063 & $9.381^{* *}$ & 0.000 & Direct effect \\
\hline \hline $\mathrm{SD} \rightarrow \mathrm{CA}$ & 0.112 & 0.049 & $2.286^{*}$ & 0.004 & Indirect effect \\
\hline $\mathrm{ED} \rightarrow \mathrm{CA}$ & -0.004 & 0.070 & $0.057-$ & 0.955 & Indirect effect \\
\hline Env.D $\rightarrow$ CA & -0.125 & 0.114 & -1.096 & 0.062 & Indirect effect \\
\hline Leg.D $\rightarrow$ CA & 0.254 & 0.070 & $3.629^{* *}$ & 0.000 & Indirect effect \\
\hline
\end{tabular}

Source: Authors.

Focusing on the direct effects of CSR variables on competitive advantage, findings shown in Table 9 indicate that, the statistical significance of the regression coefficients $(\beta)$ is proven for each of (SD, ED, Leg.D). This is supported by the calculated values of $(t)$ for the dimensions, and the statistical significance values ( $p$-value) for the mentioned dimensions are less than the significance level $(\alpha=0.05)$. So, there exists a statistically significant direct impact for social responsibility dimensions represented by (SD, ED, Leg.D) on competitive advantage (CA). In light of the previous findings, the null hypothesis (H0.5.a) was rejected and the alternative hypothesis (H1.5.a) was accepted which states that there exists a statistically significant direct impact at the significance level $(\alpha \leq 0.05)$, for the social responsibility dimensions represented by (SD, ED, Leg.D) on the achievement of competitive advantage (CA).

After the completion of hypotheses testing process, the total values of the direct and indirect effects were calculated and shown in the following Table 10.

Table 10. Results of the total (the direct and indirect) effect analysis of CSR represented by (SD, ED, Env.D, Leg.D) on competitive advantage (CA) through company reputation (CR) as a mediator variable.

\begin{tabular}{||l|l||l|l||l||l|l||}
\hline \hline \multirow{2}{*}{ No. } & $\begin{array}{l}\text { CSR } \\
\text { Dimensi } \\
\text { ons }\end{array}$ & $\begin{array}{l}\text { Rogression coefficients } \\
\text { Reputation }\end{array}$ & $\begin{array}{l}\text { Competitive } \\
\text { advantage }\end{array}$ & $\begin{array}{l}\text { Direct and } \\
\text { indirect } \\
\text { effects }\end{array}$ & $\begin{array}{l}\text { Statistical } \\
\text { decision }\end{array}$ & Result \\
\hline \hline 1 & SD & 0.236 & 0.112 & 0.348 & $\begin{array}{l}\text { Rejected } \\
\text { H0.5 }\end{array}$ & $\begin{array}{l}\text { Significant } \\
\text { impact }\end{array}$ \\
\hline 2 & ED & 0.216 & -0.004 & 0.212 & $\begin{array}{l}\text { Rejected } \\
\text { H0.5 }\end{array}$ & $\begin{array}{l}\text { Significant } \\
\text { impact }\end{array}$ \\
\hline 3 & Env. D & 0.148 & -0.125 & 0.023 & $\begin{array}{l}\text { Accepted } \\
\text { H0.5 }\end{array}$ & $\begin{array}{l}\text { Significant } \\
\text { impact }\end{array}$ \\
\hline
\end{tabular}




\begin{tabular}{|c|c|c|c|c|c|c|}
\hline 4 & Leg. D & 0.347 & 0.254 & 0.601 & $\begin{array}{l}\text { Rejected } \\
\text { H0.5 }\end{array}$ & $\begin{array}{l}\text { Significant } \\
\text { impact }\end{array}$ \\
\hline
\end{tabular}

Source: Authors.

It is evident from the results shown in Table 10 the existing statistically significant impact at the significance level $(\alpha \leq 0.05)$, for the social dimension (SD) in the competitive advantage (CA) through company reputation (CR) as a mediator variable. Also, there exists a statistically significant impact at the significance level $(\alpha \leq 0.05)$, for the ethical dimension (ED) in the competitive advantage (CA) through company reputation (CR) as a mediator variable. Contrary to the results above, data analysis indicates that, there is no statistically significant impact at the significance level $(\alpha$ $\leq 0.05$ ), for the environmental dimension (Env. D) in the competitive advantage (CA) through company reputation (CR) as a mediator variable. And finally, results indicated the existing statistically significant impact at the significance level $(\alpha \leq$ 0.05), for the legal dimension (Leg. D) in the competitive advantage (CA) through company reputation $(\mathrm{CR})$ as a mediator variable.

\section{Discussion and Conclusions}

Findings of this research illustrated the intra-relations of CSR activities, company reputation, and competitive advantage. It offered further insight into this relationship through tracking the effect of each of CSR dimensions namely, the social (SD), the ethical (ED), the environmental (Env.D), and the legal (Leg. D) on competitive advantage. This evaluation was accomplished taking into account the direct and indirect effect of CSR activities on company reputation and its reflection on firms' ability to gain competitive advantage.

The results prove the existence of a positive connection between CSR activities and competitiveness. In other words, CSR activities contribute in enhancing firms' competitiveness through the mediating role of company reputation. This finding is in accordance with previous studies on CSR (Turyakira et al., 2014; Tantalo et al., 2012; Loikkanen and Hyytinen, 2011; Zsolnai, 2006). In more detail, the results indicated a considerable positive influence of each of the social (SD), legal (Leg. D) and the ethical (ED) dimensions on the achievement of competitive advantage, the finding which has been confirmed by various scholars.

On the other hand, either through adopting the direct or the indirect track, results indicated that, the environmental activities (Env. D) implemented by tourism and hospitality service providers in Jordan market have no significant effect on firms' capabilities related to competitive advantage. It is worth noting that, such a result is inconsistent with the findings of many previous studies on CSR (Farinos, 2015; Lyon and Maxwell, 2008; Guenther et al., 2006; Williams, 2002). A plausible explanation for this inconsistency is that, the context of the present study is different as it is conducted in a developing country where consumer environmental awareness is relatively missing, unlike the bulk body of CSR research which have been held 
in Western cultures, where differences in the environment and the culture between both contexts highly affect respondents perceptions and evaluation process as Mokhtar et al. (2009) emphasized.

Finally, results of the paper diagnosed the shortcomings associated with firms Environmental Corporate Social Responsibility (ECSR) implementations and consumers perception regarding it. Also, taking into account the context (i.e. developing market) the study was conducted in, it is therefore hoped that it would contribute to generate interest towards the concept of "Environmental Corporate Social Responsibility“ (ECSR), as a strategic alternative (Rashid et al., 2014) for enhancing the positive mental image and company reputation which in turn will act as a mediator variable for the achievement of competitive advantage.

\section{References:}

Abbott, W.E., Monsen, R.J. 1979. On the measurement of corporate social responsibility: Self-reported disclosures as a method of measuring corporate social involvement. Academy of Management Journal, 22(3), 501-515. https://doi.org/10.5465/255740.

Al Muala, A.M., Al Qurneh, M. 2010. Assessing the Relationship between Marketing Mix and Loyalty through Tourists Satisfaction in Jordan Curative Tourism. American Academic \& Scholarly Research Journal, 4(2), 1-14.

Al Qeed, M.A. 2015. The Relationship between Corporate Social Responsibility toward the Employees and Hotel Industry Performance in Jordan. International Business Research, 8(1), 197-202. https://doi.org/10.5539/ibr.v8n1p197.

Al-Saidat, Z.M. 2015. The Extent of Response to Social Responsibility Accounting in Tourism Sector: A Case of Jordan. European Journal of Accounting, Auditing and Finance Research, 3(9), 75-85.

Aras, G., Aybars, A., Kutlu, O. 2010. Managing Corporate Performance: Investigating the Relationship between Corporate Social Responsibility and Financial Performance in Emerging Markets. International Journal of Productivity and Performance Management, 59(3), 229-254. https://doi.org/10.1108/17410401011023573.

Alrousan, R., Bader, M. 2015. Stakeholders Approach in Influencing Corporate Social Responsibility: A Case Study at Two Hotels in Jordan. Int. J. Tourism Policy, 6(1), 17-28. https://doi.org/10.1504/ijtp.2015.075135.

Banyte, J., Brazioniene L., Gadeikiene, A. 2010. Expression of Green Marketing Developing the Conception of Corporate Social Responsibility. Inzinerine Ekonomika-Engineering Economics, 21(5), 550-560.

Becchetti, L., Trovato, G. 2011. Corporate Social Responsibility and Firm Efficiency: A Latent Class Stochastic Frontier Analysis. Journal of Productivity Analysis, 36(3), 231246. https://doi.org/10.1007/s11123-011-0207-5.

Carroll, A.B. 1979. A three-dimensional conceptual model of corporate performance. Academy of Management Review, 4(4), 497-505. https://doi.org/10.5465/amr.1979.4498296.

Cronbach, L.J., Shavelson, R.J. 2004. My Current Thoughts on Coefficient Alpha and Successor Procedures. Educational and Psychological Measurement, 64(3), 391418. https://doi.org/10.1177/0013164404266386.

Drucker, P.F. 1954. The Practice of Management. New York, Harper \& Brothers. 
Farinos, J.M. 2015. Environmental responsibility and corporate social responsibility. VITRUVIO - International Journal of Architectural Technology and Sustainability, [S.1.], 1, 87-91. https://doi.org/10.4995/vitruvio-ijats.2015.4477.

Filho, J., Wanderley, L., Gómez, C., Farache, F. 2010. Strategic Corporate Social Responsibility Management for Competitive Advantage. Brazilian Administration Review, 7(3), 294-309. https://doi.org/10.1590/S1807-76922010000300006.

Freeman, R.E. 1984. Strategic Management: A Stakeholder Approach. Pitman, Boston. https://doi.org/10.1017/cbo9781139192675.003.

Fülöp, G., Hisrich, R., Szegedi, K. 2000. Business Ethics and Social Responsibility in Transition Economies. Journal of Management Development, 19(1), 5-31. https://doi.org/10.1108/02621710010308135.

Futa, S.M. 2013. The Relationship Between Social Responsibility and Organizational Citizenship Behavior in 5 Stars Hotels Operating in Petra City. European Scientific Journal, 9(14), 118-133.

Galant, A., Cadez, S. 2017. Corporate Social Responsibility and Financial Performance Relationship: A Review of Measurement Approaches. Economic Research-Ekonomska Istraživanja, 30(1), 676-693. https://doi.org/10.1080/1331677x.2017.1313122.

Gond, J.P., El Akremi, A., Swaen, V. 2010. Corporate Social Responsibility Influence on Employees. ICCSR Research Paper Series, International Center for Corporate Social Responsibility, Nottingham University Business School, No. 54-2010.

Guenther, E., Hoppe, H., Poser, C. 2006. Environmental corporate social responsibility of firms in the mining and oil and gas industries: Current status quo of reporting following GRI guidelines. Greener Management International, 53, 6-25. https://doi.org/10.9774/gleaf.3062.2006.sp.00003.

Ha-Brookshire, J. 2017. Toward Moral Responsibility Theories of Corporate Sustainability and Sustainable Supply Chain, Journal of Business Ethics, 145(2), 227-237. https://doi.org/10.1007/s10551-015-2847-2.

Hick, S. 2000. Morals Maketh The money. Australian CPA, 70(4), 72-73.

IndexMundi. 2019. Jordan Economy Profile 2019. https://www.indexmundi.com/jordan/economy_profile.html

Jones, M.T. 1999. The Institutional Determinants of Social Responsibility. Journal of Business Ethics, 20, 2,163-169. https://doi.org/10.1023/a:1005871021412.

Joshi, R., Sun, L., Mann, R. 2010. Dissecting the functional specificities of two Hoxproteins. Genes Dev, 24(14), 1533-1545. https://doi.org/10.1101/gad.1936910.

Loikkanen, T., Hyytinen, K. 2011. Corporate Social Responsibility and Competitiveness Empirical Results and Future Challenges. 13th Environmental Management Accounting Network (EMAN) Research Book. https://doi.org/10.1007/978-94-007-1390-1_7.

Lyon, T.P., Maxwell, J.W. 2008. Corporate social responsibility and the environment: A theoretical perspective. Review of Environmental and Policy. Oxford University Press, 1(10), 1-22. https://doi.org/10.1093/reep/ren004.

Margarita, T. 2004. Corporate Social Responsibility and Financial Performance. Center for Responsible Business. California Digital Library.

Margolis, J.D., Elfenbein, H.A., Walsh, J.P. 2011. Does it Pay to Be Good and Does it Matter? A Meta-Analysis of the Relationship between Corporate Social and Financial Performance. https://doi.org/10.2139/ssrn.1866371.

Mokhtar, S.S.M., Yusoff, R.Z., Arshad, R. 2009. Market Orientation Critical Success Factors of Malaysian Manufacturers and Its Impact on Financial Performance. International Journal of Marketing Studies, 1(1), 77-84. https://doi.org/10.5539/ijms.v1n1p77. 
Noyan, A., Bostanci, Y. 2013. Changes In Organization Policy According To Environmental Values And How Environmental Values Affect Corporate Perception In The Healthcare Sector In Turkey. 13th Sgem Geo conference On Ecology, Economics, Education And Legislation. https://doi.org/10.5593/sgem2013/be5.v1/s20.023.

O'Brien, D. 2001. Integrating Corporate Social Responsibility with Competitive Strategy. The Center for Corporate Citizenship at Boston College. J. Mack Robinson College of Business. Georgia State University.

Rashid, N.R.N.A., Rahman, N.I.A., Khalid, S.A. 2014. Environmental Corporate Social Responsibility (ECSR) as a Strategic Marketing Initiatives. Procedia - Social and Behavioral Sciences, 130(10), 499-508. https://doi.org/10.1016/j.sbspro.2014.04.058.

Roman, R.M., Hayibor, S., Agle, B.R. 1999. The Relationship between Social and Financial Performance Repainting a Portrait. Business \& Society, 38(1), 109-125. https://doi.org/10.1177/000765039903800105.

Saeed, M., Arshad, F. 2012. Corporate social responsibility as a source of competitive advantage: The mediating role of social capital and reputational capital. Journal of Database Marketing \& Customer Strategy Management, 19(4), 219-232. https://doi.org/10.1057/dbm.2012.19.

Soelton, M., Y. Ramli, Y., Anggraini, D. Khosasi, D. 2020. Implementing Good Corporate Governance to Engage Corporate Social Rerponsibility in Financial Performance. European Research Studies Journal, 23(1), 239-258. https://doi.org/10.35808/ersj/1547.

Tantalo, C., Caroli, M.G., Vanevenhoven, J. 2012. Corporate social responsibility and SME's competitiveness. Int. J. Technology Management, 58(1/2), 129-151. https://doi.org/10.1504/ijtm.2012.045792.

Turyakira, P., Venter, E., Smith, E. 2014. The impact of corporate social responsibility factors on the competitiveness of small and medium-sized enterprises. S. Afr. j. econ. manag. sci. 17(2). https://doi.org/10.4102/sajems.v17i2.443.

UNPA. 2019. About Jordan. At: https://jordan.unfpa.org/en/about-jordan.

Weshah, S.R, Dahiyat, A.A., Abu Awwad, M.R., Hajjat, E.S. 2012. The Impact of Adopting Corporate Social Responsibility on Corporate Financial Performance: Evidence from Jordanian Banks. Interdisciplinary Journal of Contemporary Research in Business, 4(5), 34-44.

Williams, A. 2002. Linking the Environmental and Social Dimensions of Corporate Social Responsibility. International Conference of the Greening of Industry Network, 1-23.

Wolska, G., Bąk, I., Oesterreich, M., Hawlena, J. 2020. Institutions in the context of implementing the CSR concept and social trust. European Research Studies Journal, 23(3), 131-146. DOI: 10.35808/ersj/1629.

Zieliński, M., Jonek-Kowalska, I. 2020. Profitability of CSR Activities from the Perspective of CS Managers. European Research Studies Journal, 23(2), 264-280. DOI: $10.35808 /$ ersj/1593.

Zsolnai, L. 2006. Competitiveness and Corporate Social Responsibility. FEEM Working Paper No. CRS 2.2006. https://doi.org/10.2139/ssrn.984774. 